\title{
Descriptive Analysis of American Culture, Values, and Beliefs
}

\author{
Ningxin Li
}

\begin{abstract}
Culture is a term that can be described as many different inter-related meanings according to the characteristics of a group of people who share similar beliefs and values (Datesman \& Kearny, 2005). The aim of a quantitative study is to classify and count statistics, and to interpret the data in relation to the research problem under investigation. This research will give a brief overview of the cultural values of Americans. The research process includes collecting variables and evaluating measurements. This research quantitatively examines Americans' culture, values, and beliefs, such as their religious preference, educational choice, preferable number of children, number of hours worked per week, sex values, and family income situations, and to see if these variables represent Americans' views. This research will explore the differences of ideas between Americans and their views towards different issues, as well as to discover facts about their beliefs and preferences in their lives. This analysis will enhance the understanding of shared cultures and promote communication for people who come from different backgrounds.
\end{abstract}

Keywords: Descriptive analysis, Skewness and Kurtosis, total family income

\section{Descriptive Analysis of American Culture, Values, and Beliefs}

American culture and lifestyles can be unique and different from other nations around the world (Datesman, JoAnn,\& Kearny, 2005). Culture encompasses many different fields such as their attitudes towards family, education, religious preference, lifestyle, and work ethic. Social Identity Theory indicates that certain groups categorize themselves as one group (Tajfel \& Turner, 1979). Social identity theory emphasizes analyzing the ingroup differences and how people maintain a positive relationship within the culture of society. A social group with different social classes and families would form a sense of self-esteem and self-recognition, as well as having a sense of their roles within the social world (Tajfel \& Turner, 1979).

This research of the opinions of Americans is based on General Social Survey. Understanding religious phenomena in the United States was one of the essential knowledges of learning social sciences and cultures (Abrams \& Hogg, 1990). Quantitative data gives the researcher a view of details of a larger sample. It is based on discovering facts and the results are clearly shown through objective data. The researcher wants to understand what religious preferences Americans have. What is the highest educational degree an American has? How many children do they have? How many hours do they work per week? This study also tests the family income variable in a quantitative descriptive statistics study. The researcher chooses quantitative descriptive statistics method to provide information about variables and to highlight potential relationships between different variables (Healey, 1990). For example, the researcher will analyze the measures of Central Tendency and Dispersion. Measures of central tendency including analyzing the mean, median, and mode (Healey, 1990). It will enhance the understanding of each variable and the relationships between different variables.

American Values and Beliefs

\begin{tabular}{|c|c|c|c|c|c|c|}
\hline Variable Name & $\begin{array}{ll}\text { Level } & \text { of } \\
\text { Measurement }\end{array}$ & Mode & Median & Mean & Range & $\begin{array}{l}\text { Standard } \\
\text { Deviation }\end{array}$ \\
\hline $\begin{array}{l}\text { Sex } \\
\text { Religion } \\
\text { race }\end{array}$ & Nominal & $\begin{array}{l}2 \\
1 \\
1\end{array}$ & & & & \\
\hline $\begin{array}{l}\text { Degree } \\
\text { Level of } \\
\text { happiness } \\
\text { Views of sex } \\
\text { before marriage }\end{array}$ & Ordinal & $\begin{array}{l}1 \\
2 \\
4\end{array}$ & $\begin{array}{l}2 \\
2 \\
3\end{array}$ & & & \\
\hline $\begin{array}{l}\text { hours of work } \\
\text { Numbers of } \\
\text { children } \\
\text { Age } \\
\text { Income }\end{array}$ & Interval/ratio & $\begin{array}{l}40 \\
0 \\
48 \\
\\
18\end{array}$ & $\begin{array}{l}40 \\
2 \\
45 \\
\\
18\end{array}$ & $\begin{array}{l}42.13 \\
1.86 \\
46.88 \\
\\
16.39\end{array}$ & $\begin{array}{l}95 \\
8 \\
71 \\
\\
24\end{array}$ & $\begin{array}{l}14.16 \\
1.639 \\
17.086 \\
\\
5.579\end{array}$ \\
\hline
\end{tabular}



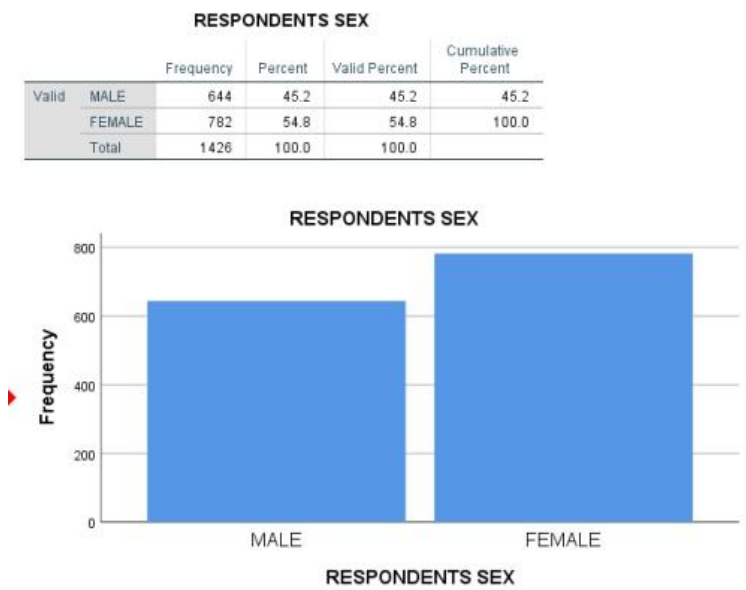

\section{Statistics}

\section{RESPONDENTS SEX}

\begin{tabular}{llr}
\hline N & Valid & 1426 \\
\cline { 2 - 3 } & Missing & 0 \\
\hline Mode & & 2 \\
\hline
\end{tabular}

Data are formed of statistics and were arranged in graphs, tables, and charts. For example, age of Americans is a common demographic question and will be recorded in this research. There was a total 1,426 people who responded to the survey. The data were chosen from the General Social Survey database. Variables included nominal, ordinal, and ratio variables (Healey, 1990). There were numbers of hours people worked last week, number of children, age, highest degree, sex, total family income, religious preference, general happiness, sex before marriage, and race. In this test, the researcher wants to know the relationship between male and female in the United States. The sex variable for the descriptive frequency is one for male, two for female. For the central tendency, the female occurs the most frequently based on mode data. Frequency for females is 782 , and frequency for males is 644 . The percentage of males is $45.2 \%$, and for females is $54.8 \%$.

\section{Statistics}

RS RELIGIOUS PREFERENCE

\begin{tabular}{|c|c|c|}
\hline \multirow[t]{2}{*}{$N$} & Valid & 1417 \\
\hline & Missing & 9 \\
\hline & & 1 \\
\hline
\end{tabular}

RS RELIGIOUS PREFERENCE

\begin{tabular}{ll|r|r|r|r} 
& & Frequency & Percent & Valid Percent & $\begin{array}{c}\text { Cumulative } \\
\text { Percent }\end{array}$ \\
\hline \multirow{2}{*}{ Valid } & PROTESTANT & 765 & 53.6 & 54.0 & 54.0 \\
\cline { 2 - 7 } & CATHOLIC & 362 & 25.4 & 25.5 & 79.5 \\
\cline { 2 - 7 } & JEWISH & 27 & 1.9 & 1.9 & 81.4 \\
\cline { 2 - 7 } & NONE & 227 & 15.9 & 16.0 & 97.5 \\
\cline { 2 - 7 } & OTHER (SPECIFY & 36 & 2.5 & 2.5 & 100.0 \\
\cline { 2 - 7 } & Total & 1417 & 99.4 & 100.0 & \\
\hline Missing & NA & 9 & .6 & & \\
\hline Total & & 1426 & 100.0 & & \\
\hline
\end{tabular}



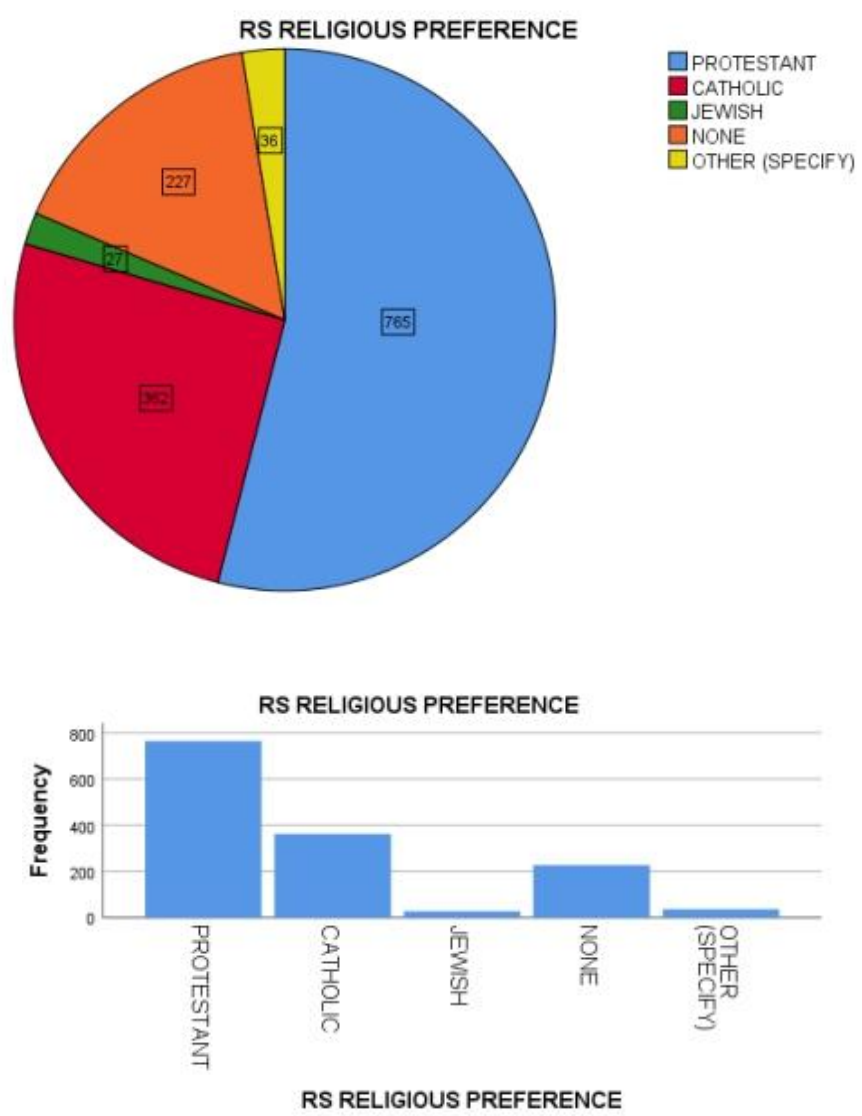

In the United States, people are from different countries and brought their cultures here. They have all types of religions, and people speak languages from different parts of the world (Datesman, JoAnn \& Kearny, 2005).Quantitative research can measure religious variables and give people ideas about who is religious and who is not. The researcher wants to know: What are the religious preferences of typical Americans? When we see the variable of religious preference in the graph, we have variables, such as Protestant, Catholic, Jewish, none, and other. When analyzing the descriptive statistics, the total valid cases are 1,417, missing cases are 9. The mode is 1 , which is Protestant. The statistic shows that Protestant has 54\%, Catholic has 25.5\%, Jewish has 1.9\%, none is 16\%, and other population is $2.5 \%$ respectively.

\section{Statistics}

\section{RS HIGHEST DEGREE}

\begin{tabular}{|c|c|c|}
\hline \multirow[t]{2}{*}{ N } & Valid & 1425 \\
\hline & Missing & 1 \\
\hline \multicolumn{2}{|c|}{ Median } & 1.00 \\
\hline \multicolumn{2}{|c|}{ Mode } & 1 \\
\hline
\end{tabular}

\section{RS HIGHEST DEGREE}

\begin{tabular}{|c|c|c|c|c|c|}
\hline & & Frequency & Percent & Valid Percent & $\begin{array}{l}\text { Cumulative } \\
\text { Percent }\end{array}$ \\
\hline \multirow[t]{6}{*}{ Valid } & LT HIGH SCHOOL & 216 & 15.1 & 15.2 & 15.2 \\
\hline & HIGH SCHOOL & 728 & 51.1 & 51.1 & 66.2 \\
\hline & JUNIOR COLLEGE & 127 & 8.9 & 8.9 & 75.2 \\
\hline & BACHELOR & 247 & 17.3 & 17.3 & 92.5 \\
\hline & GRADUATE & 107 & 7.5 & 7.5 & 100.0 \\
\hline & Total & 1425 & 99.9 & 100.0 & \\
\hline Missing & NA & 1 & 1 & & \\
\hline Total & & 1426 & 100.0 & & \\
\hline
\end{tabular}




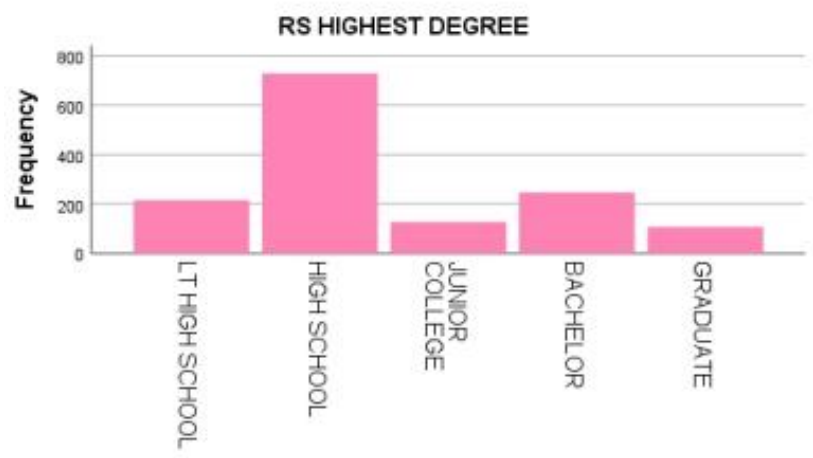

This research also tests Americans' highest level of education. The median of the distribution is 1, the valid number of cases are 1,425 , and the missing data value is 1 . The mode 1 is associated with the population of those with a high school diploma. When looking at the frequency, 216 is for less than high school degree, 728 is for high school students, 127 is for junior college, 247 is for bachelor's degree, and 107 is for graduate degree.

Statistics

\begin{tabular}{|c|c|c|}
\hline \multicolumn{2}{|c|}{ NUMBER OF CHILDREI } & \multirow[b]{2}{*}{1421} \\
\hline \multirow[t]{2}{*}{$\mathrm{N}$} & Valid & \\
\hline & Missing & 5 \\
\hline \multicolumn{2}{|c|}{ Mean } & 1.86 \\
\hline \multicolumn{2}{|c|}{ Median } & 2.00 \\
\hline \multicolumn{2}{|c|}{ Mode } & 0 \\
\hline \multicolumn{2}{|c|}{ Std Deviation } & 1.639 \\
\hline \multicolumn{2}{|c|}{ Variance } & 2.886 \\
\hline \multicolumn{2}{|c|}{ Skewness } & .864 \\
\hline \multicolumn{2}{|c|}{ Std. Error of Skewness } & .065 \\
\hline \multicolumn{2}{|c|}{ Kurtosis } & .776 \\
\hline \multicolumn{2}{|c|}{ Sta. Error of Kuntogis } & .130 \\
\hline \multicolumn{2}{|c|}{ Range } & 8 \\
\hline
\end{tabular}

NUMBER OF CHILDREN

\begin{tabular}{|c|c|c|c|c|c|}
\hline \multicolumn{6}{|c|}{ NUMBER OF CHILDREN } \\
\hline & & Frequency & Percent & Valid Percent & $\begin{array}{c}\text { Cumulative } \\
\text { Percent }\end{array}$ \\
\hline \multirow[t]{10}{*}{ Valid } & 0 & 385 & 27.0 & 27.1 & 27.1 \\
\hline & 1 & 230 & 16.1 & 16.2 & 43.3 \\
\hline & 2 & 364 & 25.5 & 25.6 & 68.9 \\
\hline & 3 & 241 & 16.9 & 17.0 & 85.9 \\
\hline & 4 & 112 & 7.9 & 7.9 & 93.7 \\
\hline & 5 & 43 & 30 & 3.0 & 96.8 \\
\hline & 6 & 27 & 1.9 & 1.9 & 98.7 \\
\hline & 7 & 11 & 8 & 8 & 99.4 \\
\hline & EIGHT OR YORE & $B$ & 6 & 6 & 1000 \\
\hline & Totai & 1421 & 99.6 & 100.0 & \\
\hline Missing & DKNA & 5 & 4 & & \\
\hline Total & & 1426 & 1000 & & \\
\hline
\end{tabular}

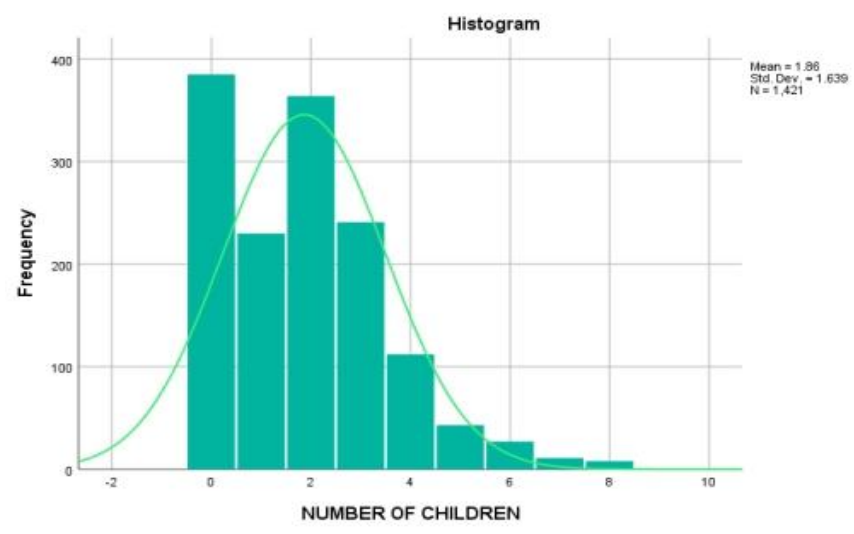


Americans' view about the ideal number of children in a family might have changed over the years. Quantitative descriptive study illustrates the logical links between numbers (Field, 2018). This test shows how many children an American has. For this test, the total valid cases are 1,421, missing cases are 5. In addition, the mean is 1.86 , the median is 2 , and the mode is 0 . The variance is 2,686 and the range is 8 . The indicator for the central tendency will be used to analyze the mean, median, and mode for the distribution. For the dispersion, the researcher will analyze standard deviation, variance, range, and choose Skewness and Kurtosis for data analysis. It shows that the histogram is a positive skew and a positive Kurtosis.
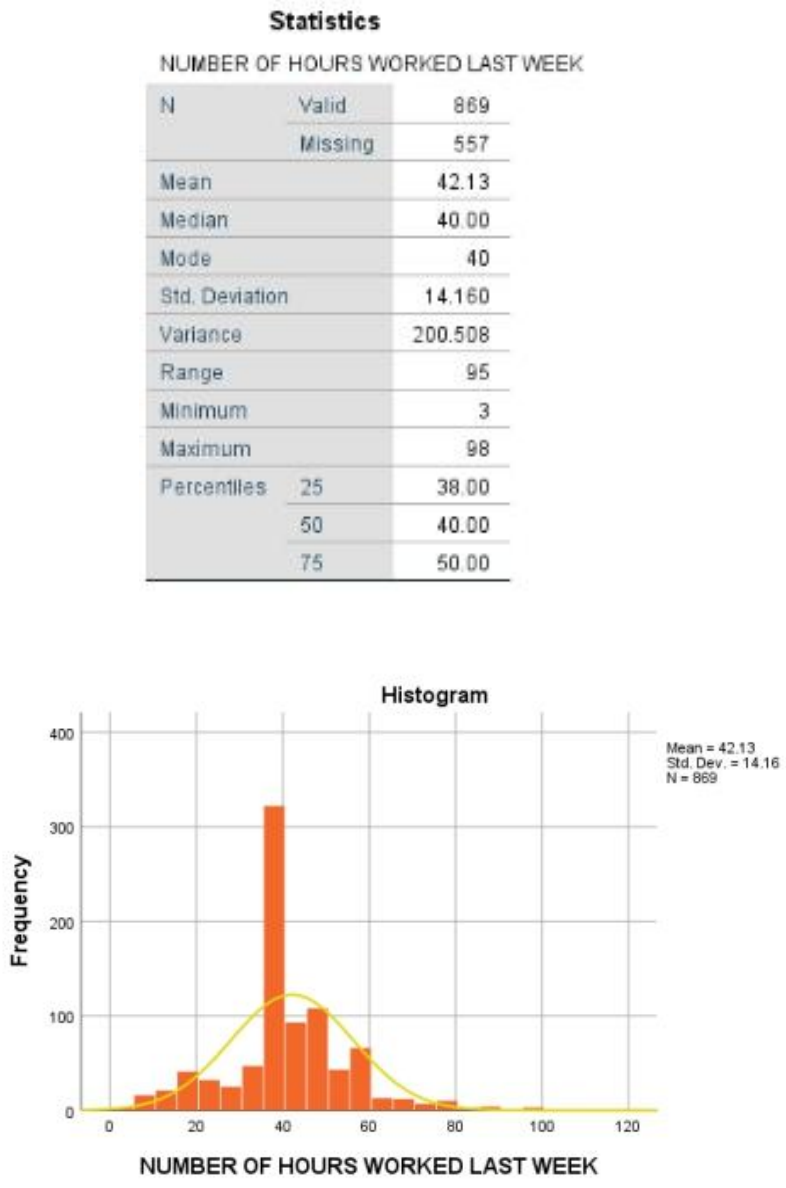

\section{Average Hours Per Week Worked in the United States}

Histograms provide a clear representation of the frequency of the data. Frequency is how often the variables occurs (Healey, 1990). Americans have a sense of pride in being responsible for themselves and know that other people also expect them to be independent (Datesman, JoAnn \& Kearny, 2005). The previous study shows that Americans work more in the industrialized world, and workforce participation in the United States has increased, which means that Americans have to work longer hours so that they could gain more income (Isidore \& Luhby, 2015). Despite Americans belief that spending time with their friends and family and being with other people is important in their culture, Americans are hard workers and understand their roles in a career and their ability to participate in society. This test is to investigate how many hours Americans worked within a week and the average amount of hours. This histogram shows the different number of hours Americans worked within a week. There are 869 valid cases and 557 missing cases. The mean is 42.13 , the median is 40 , the mode is 40 , the standard deviation is 14.16 , and the range is 95 . The frequency distribution shows that there was one person who worked 3 hours, 8 people who worked 10 hours, 27 individuals who worked 20 hours, and 278 people who worked 40 hours. 


\begin{tabular}{llrr}
\multicolumn{3}{c}{$\begin{array}{c}\text { Statistics } \\
\text { GENERAL } \\
\text { HAPPINES }\end{array}$} & $\begin{array}{c}\text { SEXBEFORE } \\
\text { MARRIAGE }\end{array}$ \\
\hline $\mathrm{N}$ & Valid & 961 & 603 \\
\cline { 2 - 4 } & Missing & 465 & 823 \\
\hline Mean & 1.79 & 2.93 \\
\hline Median & 2.00 & 3.00 \\
\hline Mode & 2 & 4 \\
\hline Std. Deviation & .652 & 1.252 \\
\hline Variance & .425 & 1.568 \\
\hline Range & 2 & 3 \\
\hline Minimum & 1 & 1 \\
\hline Maximum & & 3 & 4 \\
\hline Percentiles & 25 & 1.00 & 2.00 \\
\cline { 2 - 5 } & 50 & 2.00 & 3.00 \\
\cline { 2 - 5 } & 75 & 2.00 & 4.00 \\
\hline
\end{tabular}

GENERAL HAPPINESS

\begin{tabular}{ll|r|r|r|r} 
& & & & \multicolumn{1}{c}{$\begin{array}{c}\text { Cumulative } \\
\text { Percent }\end{array}$} \\
\hline \multirow{3}{*}{ Valid } & VERY HAPPY & 324 & 22.7 & 33.7 & 33.7 \\
\cline { 2 - 7 } & PRETTY HAPPY & 512 & 35.9 & 53.3 & 87.0 \\
\cline { 2 - 7 } & NOT TOO HAPPY & 125 & 8.8 & 13.0 & 100.0 \\
\cline { 2 - 7 } & Total & 961 & 67.4 & 100.0 & \\
\hline \multirow{4}{*}{ Missing } & NAP & 462 & 32.4 & & \\
\cline { 2 - 7 } & DK & 3 & .2 & & \\
\cline { 2 - 7 } & Total & 465 & 32.6 & & \\
\hline \multirow{2}{*}{ Total } & 1426 & 100.0 & & \\
\hline
\end{tabular}

Americans might have different lifestyles and ways of considering happiness. American people believe in freedom of choice. They are mostly friendly and like to say, "Good morning" or "How are you doing" as a greeting in a communication. For the variable of general happiness, the mean is 1.79 , the median is 2 , and the mode is 2 . There were 324 people who responded that they were very happy, 521 people who responded that they were pretty happy, and 125 people who responded that they were not too happy. The highest percentage is $53.3 \%$ of people, who indicated that they were pretty happy.

\begin{tabular}{|c|c|c|c|c|c|}
\hline \multicolumn{6}{|c|}{ SEX BEFORE MARRIAGE } \\
\hline & & Frequency & Percent & Valid Percent & $\begin{array}{c}\text { Cumulative } \\
\text { Percent }\end{array}$ \\
\hline \multirow[t]{5}{*}{ Valid } & ALWAYS WRONG & 150 & 10.5 & 24.9 & 24.9 \\
\hline & ALMST ALWAYS WRO & 46 & 3.2 & 7.6 & 32.5 \\
\hline & SOMETIUES WRONO & 106 & 7.4 & 17.6 & 50.1 \\
\hline & NOT WRONG AT ALL & 301 & 21.1 & 49.9 & 100.0 \\
\hline & Total & 603 & 42.3 & 100.0 & \\
\hline \multirow[t]{4}{*}{ Missing } & NAP & 806 & 56.5 & & \\
\hline & DK & 13 & .9 & & \\
\hline & NA & 4 & 3 & & \\
\hline & Total & 823 & 57.7 & & \\
\hline Total & & 1426 & 100.0 & & \\
\hline
\end{tabular}

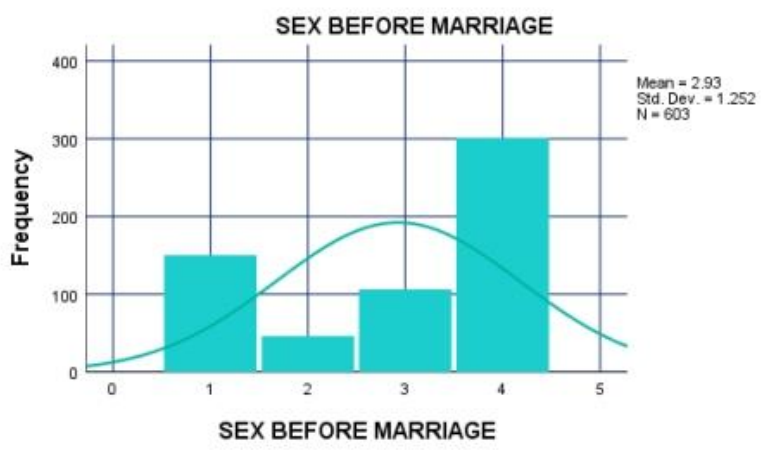


In addition, for the variable of sex before marriage, the mean is 2.93 , the median is 3 , and the mode is 4 . There were 150 people who responded that sex before marriage was always wrong, 46 indicated that it was almost always wrong, 106 indicated that it was sometimes wrong, and 301 people indicated that sex before marriage was not wrong at all. However, the highest population of $49.9 \%$ believed that sex before marriage was not wrong at all.

Also, when people who have different backgrounds interact with each other, their culture became more diverse, while differences such as income standard and age should be used as the basis for interacting with others (Tajfel, 1981).

\section{Statistics}

TOTAL FAMILY INCOME

\begin{tabular}{|c|c|c|}
\hline \multirow[t]{2}{*}{$N$} & Valid & 1205 \\
\hline & Missing & 221 \\
\hline \multicolumn{2}{|c|}{ Mean } & 16.39 \\
\hline \multicolumn{2}{|c|}{ Median } & 18.00 \\
\hline \multicolumn{2}{|c|}{ Mode } & 18 \\
\hline \multicolumn{2}{|c|}{ Std. Deviation } & 5.579 \\
\hline \multicolumn{2}{|c|}{ Variance } & 31.129 \\
\hline \multicolumn{2}{|c|}{ Range } & 24 \\
\hline
\end{tabular}

Total Family Income

\begin{tabular}{|c|c|c|c|c|c|}
\hline & & Frequency & Percent & Valid Percent & $\begin{array}{l}\text { Cumulative } \\
\text { Percent }\end{array}$ \\
\hline \multirow[t]{26}{*}{ Valid } & UNDER \$1 000 & 14 & 1.0 & 1.2 & 1.2 \\
\hline & $\$ 1000$ TO 2999 & 13 & .9 & 1.1 & 2.2 \\
\hline & $\$ 3000$ TO 3999 & 13 & .9 & 1.1 & 3.3 \\
\hline & $\$ 4000$ TO 4999 & 6 & .4 & .5 & 3.8 \\
\hline & $\$ 5000$ TO 5999 & 9 & .6 & .7 & 4.6 \\
\hline & $\$ 6000$ TO 6999 & 15 & 1.1 & 1.2 & 5.8 \\
\hline & $\$ 7000$ TO 7999 & 14 & 1.0 & 1.2 & 7.0 \\
\hline & $\$ 8000$ TO 9999 & 36 & 2.5 & 3.0 & 10.0 \\
\hline & $\$ 10000$ TO 12499 & 45 & 3.2 & 3.7 & 13.7 \\
\hline & $\$ 12500$ TO 14999 & 46 & 3.2 & 3.8 & 17.5 \\
\hline & $\$ 15000$ TO 17499 & 41 & 2.9 & 3.4 & 20.9 \\
\hline & $\$ 17500$ TO 19999 & 31 & 2.2 & 2.6 & 23.5 \\
\hline & $\$ 20000$ TO 22499 & 51 & 3.6 & 4.2 & 27.7 \\
\hline & $\$ 22500$ TO 24999 & 41 & 2.9 & 3.4 & 31.1 \\
\hline & $\$ 25000$ TO 29999 & 56 & 3.9 & 4.6 & 35.8 \\
\hline & $\$ 30000$ TO 34999 & 80 & 5.6 & 6.6 & 42.4 \\
\hline & $\$ 35000$ TO 39999 & 75 & 5.3 & 6.2 & 48.6 \\
\hline & $\$ 40000$ TO 49999 & 130 & 9.1 & 10.8 & 59.4 \\
\hline & $\$ 50000$ TO 59999 & 99 & 6.9 & 8.2 & 67.6 \\
\hline & $\$ 60000$ TO 74999 & 97 & 6.8 & 8.0 & 75.7 \\
\hline & $\$ 75000$ TO $\$ 89999$ & 86 & 6.0 & 7.1 & 82.8 \\
\hline & $\$ 90000$ TO \$109999 & 69 & 4.8 & 5.7 & 88.5 \\
\hline & $\$ 110000$ TO $\$ 129999$ & 47 & 3.3 & 3.9 & 92.4 \\
\hline & $\$ 130000$ TO $\$ 149999$ & 31 & 2.2 & 2.6 & 95.0 \\
\hline & \$150000 OR OVER & 60 & 4.2 & 5.0 & 100.0 \\
\hline & Total & 1205 & 84.5 & 100.0 & \\
\hline \multirow[t]{3}{*}{ Missing } & REFUSED & 145 & 10.2 & & \\
\hline & NA & 76 & 5.3 & & \\
\hline & Total & 221 & 15.5 & & \\
\hline Total & & 1426 & 100.0 & & \\
\hline
\end{tabular}




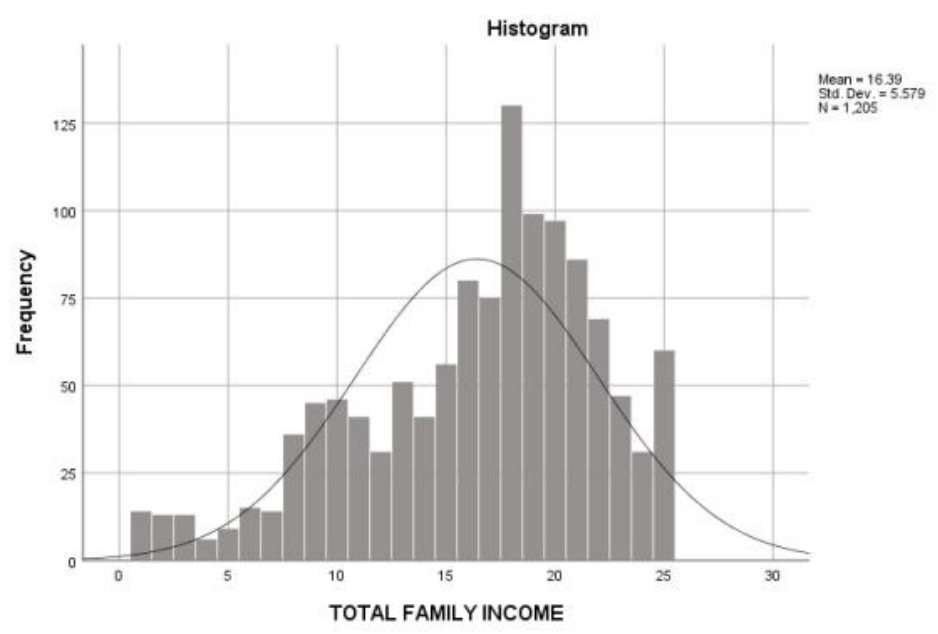

This histogram shows that when testing the variable of total family income, there is a total of 1,205 valid cases and 221 missing cases. The mean is 16.39 , the median is 18 , the mode is 18 , the standard deviation is 5.579 , and the range is 24 . The frequency distribution shows that there were 14 families who had income under $\$ 1,000,130$ families who had income between $\$ 40,000$ to $\$ 49,999,60$ families who had income of $\$ 150,000$ or over. The highest rate is $10.8 \%$ of people with an income of $\$ 40,000$ to $\$ 49,999$, and there are only $0.5 \%$ of people with an income between $\$ 4,000$ to $\$ 4,999$.

\section{Conclusion}

The United States is a diverse country, it was influenced by many different cultures. Many Americans come from different ethnic groups of their ancestors who emigrated from various nations or cultures. Personal values and behaviors reflect the culture of the society, while culture shapes people's understanding of how to express their ideas and view the world around them. People might have personal characteristics towards personal preferences. Individuals also have shared common sense and knowledge that make the group members to agree with each other. Americans believe in understanding the importance of equality of opportunity. Everyone has an equal chance for chasing their dreams and obtaining success. American values were influenced by the ideology of building a democratic nation which truly makes them unique.

\section{References}

Abrams, D. and Hogg, M. A. (1990). Social Identity Theory: Constructive and Critical Advances. London: HarvesterWheatsheaf.

Datesman, M., JoAnn C., J., \& Kearny, E., N. (2005). American Ways: An Introduction to American Culture. England: Longman.

Healey, J. F. (1990). Statistics, A Tool for Social Research. CA: Wadsworth.

Hoover, K. R. (2013). The Elements of Social Scientific Thinking. NY: St. Martin's Press. Southborough, Massachusetts. (n.d.). Understanding U.S. American Culture, Values, and Beliefs. Retrieved from https://www.stmarksschool.org/campus-life/residential-life/international-students/living-in-theus/understanding-american-culture.

Tajfel, H., \& Turner, J. C. (1979). An Integrative Theory of Intergroup Conflict. The Social Psychology of Intergroup Relations. CA: Brooks/Cole.

Tajfel, H. (1981). Human Groups and Social Categories: Studies in Social Psychology. Cambridge: Cambridge University Press. 